\title{
Just-In-Time System and Its Impact on Operational Excellence: An Empirical Study on Jordanian Industrial Companies
}

\author{
Yazan Emnawer Al haraisa ${ }^{1}$ \\ ${ }^{1}$ Faculty of Business, Tafila Technical University, At-Tafila, Jordan \\ Correspondence: Yazan Emnawer Al haraisa, Faculty of Business, Tafila Technical University, AT-Tafila, \\ P.O.Box179, Tafila, 66110, Jordan. E-mail: yazanhryza@yahoo.com
}

Received: August 20, 2017

Accepted: September 28, 2017

Online Published: November 20, 2017

doi:10.5539/ijbm.v12n12p158

URL: https://doi.org/10.5539/ijbm.v12n12p158

\begin{abstract}
Nowadays, the field of just in time and operational excellence are considered a backbone and a critical pillar for many companies in order to achieve the competitive advantages. Consequently, the main aim of this study is to define the impact of just in time system on operational excellence in the (14) manufacturing companies operating at Al -Hussein bin Abdullah II qualified industrial zone (QIZ) in Al-Karak Governorate. The sampling unit and analysis (respondents) included (168) manager and head of divisions at the production and logistic departments, and selected purposely according to their work especially in the just in time system area within the target companies. Thus, the researcher designed a questionnaire including of (25) items to gather the desired data from study sample. This study also used the multiple regression analysis to test the hypotheses. The result of the current study found that the just in time system have a positive impact on the operational excellence in Jordanian industrial companies. According to these results the study recommending that the Jordanian industrial companies must emphasis essentially and mainly on their just in time system consisted of (equipment layout, supplier's quality, Setup time reduction; Pull production) in order to enhance and attain the operational excellence and gain competitive advantage. One of the most limitations is that the current study and its finding applied on the Jordanian industrial companies especially at Al-Karak governorate. Therefore, the results of present study can't generalize on the other sectors. Therefore, there is a need to conduct more studies and research on the other sectors such as food Industry and pharmaceutical industries in order to generalize the results. In addition to, conducting comparative studies with other industrial areas located in Jordan.
\end{abstract}

Keywords: Just in time system, equipment layout, supplier's quality, Setup time reduction, Pull production, operational excellence, Jordanian industrial companies

\section{Introduction}

The Jordanian Industrial companies are a backbone and play a vital role in nation's economy (al -shbiel and al-Awaqleh, 2012). Historically, in the early of 1970 the just in time system adopted and developed by Toyota Motor company(TPC) and many firms in services and manufacturing companies have been used just in time system in order to maximize efficiency and eliminate waste to achieve the competitive advantage .

According to (Stevenson, Hendry, \& kingsman, 2005) the just in time is considered one of the most options for two components which include production planning and control systems in order to satisfying client demands and serve the expectations of business market.

The literature of just in time system has identified just in time as a system that making what customer needs and when it needs in the quantity needed by using both of minimum resource of people and materials (Kinyua, 2015). Gyampah and Gargeya (2001) described the just in time system as strategy in the long-term that can encourage excellence and reduce unused during the whole organization.

For the operational excellence is a new concept and terminology play a critical role in the industrial companies. Therefore, many organizations are looking to achieve operational excellence. According to (Fok-yew, Ahmad \& Baharin, 2013) Operational excellence does not concern about reduction the cost and quality upgrading but also is an extension to how to deal with people and resources.

On the other side, most of academic research and previous studies focused on measuring the effect of competition, just in time production and total quality management on the use of Multiple Performance measures 
such as (Eker \& Pala, 2008). Other studies emphasized measuring the effect of JIT implementation in Iran automotive industry (Rahmani \& Nayebi, 2014). And (Mazanai, 2012) study focused on impact of just-in-time inventory system on efficiency, quality and flexibility among manufacturing sector, small and medium enterprise (SMEs) in South Africa.

Moreover, some studies concentrated on the application of lean and JIT principles in supply chain management such as (Singh et al., 2013). Through revising the theoretical studies in the related topic, there are no sufficient studies and also lack preceding studies that concentrated on examination the impact of just in time on operational excellence especially in Jordanian industrial companies. Hence, the current study purposes to deepen the literature and acquire more knowledge in this area by testing empirically the impact of just in time on operational excellence in the Jordanian industrial companies'. Thus, the main question of current study is: what is the impact of just in time system on operational excellence?

\section{Literature Review}

\subsection{Just in Time System}

The concept of Just-In-Time (JIT) system is used by Japanese management and applied in manufacturing and services companies and was introduced by Shigeo Shing and Taichi Ohno at the Toyota Motor plant.

Hence, the JIT system includes the right items, right quantity and quality, right place or location in the right time. The researchers did not arrive to identify a clear and precise concept of just in time system. However, many researchers identified the concept of JIT system as a managing the material flow in a plant in order to decrease or reduce the levels of inventory (Rahmani \& Nayebi, 2014).other researchers described the concept of JIT system as a long- term strategy involve promote and encourage excellence and remove waste during the organization entire (Gyampah \& Gargeya, 2001).

According to Gupta (2012) showed that JIT system come to be a philosophy and a managerial system include a collection of management methods and used high techniques in order to improve efficient and effectiveness operations by producing the right product and right quantity, on the right time and the right place.

Voss and Robinson (1987) refers that just in time system became as a methodology of production which leads to develop and improve whole productivity during the elimination of waste in order to get better quality.

Additionally, JIT can be describing as a strategic source that leads to achieve the competitive advantage for manufacturing companies (Lewis, 2000). Many scholars suggested that just in time system is focused on pull production concept which reduces the overall inventories in warehouses, while the push system focused on pushes the equipment and materials to next stage of production (Kootanaee, Babu, \& Talari, 2013). Based on above definition, just in time can be defined as a system or strategy that used by companies and involve many activities that programed and planned in order to avoid overproduction and lead to achieve competitive advantage.

According to Kannan and Tan (2005) the main goals of using JIT system is simplifying the process of just in time system to elimination the waste and more controlling on raw materials and focusing on protective maintenance before the problem happened. According to Voss and Robinson (1987), the aims of just in time system to improve productivity indicators by elimination of waste which lead to high quality. Moreover, the main goals of just in time system improving products quality and reduce the costs by using high techniques levels (Miltenburg, 2001). In addition, the goals of just in time system is reduce set up time and inventories, emphasis on continuous improvement and knowledge of worker, layout of equipment, eliminate waste and achieve zero defects goals (Singh \& Garg, 2011).

For the principles concerning just in time technique according to (Singh et al., 2013) there are various principles regarding just in time system such as just in time human resource Principle, just in time production principle, just in time inventory Principle, just in time supplier relation principle and just in time quality principle.

Various studies have proposed that just in time system practices involve pull -production, Set-up time reduction, planning adherence and Lay-out-optimization such as (Poojary \& Kumar, 2015). And other studies summarized the practices of just in time system include equipment layout, supplier's quality, daily Schedule Adherence, set up time reduction, preventive maintenance commitment and Just-in-time delivery by supplier such as (Khaireddin, Abu Assab \& Nawafleh, 2015). Moreover, other studies take the elements of just in time such as just in time delivery by suppliers, equipment layout Setup time reduction, and daily schedule adherence and pull system (Cua \& Schroeder, 2001). Therefore, the current study focuses on the following practices of just in time system according to (Poojary \& Kumar, 2015; Khaireddin, Abu Assab, \& Nawafleh, 2015; Cua \& Schroeder, 2001): 


\subsubsection{Equipment Layout}

According to Evans(1997) the just in time system requires the implementation of a regular flow of material system, as they are submitting materials at the beginning of the process and moving without any delays until a final product. Therefore, it must be the equipment layout is a straight line or take the order of cell-shaped $\mathrm{U}$. The design of $\mathrm{U}$ is better than straight line because they have some features such as reduces setup time and provides an opportunity for employees to move between machines, as well as to facilitate communication between workers (horngren, George and dater, 2000).

Hence, some the researchers such as Abdallah and Phan (2007); Mastui (2007) have been identified the concept of equipment layout as a practices that use of smaller of equipment that designed for flexible floor layout and also use of cells of manufacturing and removal of forklifts and extended conveyors which are related with just in time system. According to Khaireddin, Abu Assab, and Nawafleh (2015), the good equipment layout can lead to a bundle of benefits such as a minimize the production cycle time and speed up production process that will help improving the flexibility of production process and performed the job on scheduled time without delay.

\subsubsection{Suppliers Quality}

According to Wong and Johansen (2006) the JIT suppliers are considered closely related with just in time system. According to Hou, Chan, and Wang (2011) the suppliers can reduce the time of distribution by a coordinate with the company closely by using accurate and clear information that can be passed to the company as soon as possible and integrated just in time system with its suppliers.

Therefore, the company should build and keep good relationships with their suppliers in order to enhance and promoting just in time system (Madanhire, Kagande \& Chidziva, 2013).

On the other hand, the manufacturer should select the suppliers based on some standards such as lower costs and quality in good time distribution (Kaneko \& Nojiri, 2008).

\subsubsection{Set up Time Reduction}

According to Abdallah and Matsu (2007) the concept of set up time reduction or lot size reduction are using to measures if the factory adopt scales to decrease set up times and lower the lot sizes in order to simplify and assist just in time system. According to Ramezani and Razmeh (2014) the setup time reduction is considered critical factors to reduce time of production which provide a widely inventory reduction through produce a small amount the product for each time you set up the machines. Hence, the reducing setup time is very important because it will increase available capacity and flexibility in order to meet schedule change and reduces inventory (Schroeder, Goldstein, \& Rungtusanatham, 2011, p. 144).

According to Singh and Ahuja (2012) the setup time reduction help the organization to produce small quantities that will be feasible from economic aspect and reduce the lead times and improve the quality and flexibility in shop floor.

\subsubsection{Pull Production}

The pull production system is the core element for just in time system. According to drury (2002) the just in time system generated from pull production system. Moreover, the pull production is useful for the all value stream. In other words, the upstream not apply to produce until downstream demand any goods or services (Ramezani \& Razmeh, 2014). In the other side, the pull system is very important because this used to manage inventory and monitoring or control flow of material which driven from downstream needs to upstream production (Adnan et al., 2013).

In sum, the pull production system is where the materials are pulled or withdraw by next level of the production when getting a request by the next level of production; this will reduce the keep of inventory (Kootanaee, Babu, \& Talari, 2013).

\subsection{Operational Excellence}

According to (Shehadeh et. al., 2016) the concept of business excellence is founded by Japanese scientists and engineers and they learned practices and techniques from Deming after the Second World War (II). On the other aspect, operational excellence is depend on many factors such as employee's empowerment, ownership and continues improvement in culture (Yew \& Ahmad, 2014).

Furthermore, the term of operational excellence can be as combined of competitive advantage and flexibility and take in account both improve customer responsiveness and cost effectiveness (Ion, Catalina \& Georgiana, 2013). (Islam, 2017) noted that the output or results in operational excellence is producing quality product and goods. 
Moreover, the operational excellence is one of the most important competitive weapons for the services and manufacturing companies (Shehadeh et. al., 2016). Therefore, scholars identified the concept of operational excellence as an incorporated management system that leads and push productivity of business by implementing demonstrated on practices and procedures through using three core elements or basic blocks such as asset productivity, capital effectiveness and operation risk management (Ifeanyichukwu, 2010).

According to Yew, Ahmad, and Baharin (2013) the operational excellence is regarding about how to deal with people and resources not just relevant with cost reduction and quality improvement.

Operational excellence is described as a method or approach that use for organization in order to reengineer its current operation ways to produce efficiently and profitably (Eriksson, pettersson and shokatloo, 2012). According to Jaegera, Matyasb and Sihn (2014), operational excellence mainly includes many elements such as efficiency, effectiveness of customer and exploit of optimization production and orientation toward market process that deal with them.

Russell and Koch (2009) described the Operational Excellence as a disciplined method that achieves the world class performance and the basics for sustainable growth.

On the other hand, Operational Excellence can be achieved through applying the tools and methods in order to change together how business is managed and what are managed within the business. This involves many business influencers such as culture, discipline, policies and procedures (Ifeanyichukwu, 2010).

Based on above definition, the operational excellence is a strategy that adopt by organizations in order to achieve the competitive advantages by using the qualified people and use effective and efficient resources to produce high quality in goods and services.

From reviewing the literature and previous studies, there is no agreement between a researchers and scholars about the dimensions of operational excellence. For instance, the dimensions of operational excellence according to $(\mathrm{Lu}, \mathrm{Betts} \& \mathrm{Croom}, 2011)$ consists of focus on the right first time, high efficiency and effectiveness and customer and market oriented. While (Serfontein, 2010) clarify that the dimensions of operational excellence involves cost management, product differentiation and integration. On the other hand, Ion, Catalina and Cioana, (2013) indicated that the dimensions of operational excellence include process focus, customer focus and World-class performance.

\section{Study Hypothesis}

The current study essentially aimed to examination the impact of just in time system on operational excellence. Therefore, the main hypothesis is:

H0: There is no impact with statistical significant at $(\alpha \leq 0.05)$ of just in time system in terms of (Equipment layout, Suppliers quality, Set up time reduction and Pull production) on operational excellence.

\section{Methodology}

The study aims to examine the impact of just in time system on operational excellence from the perspectives of mangers of the target companies. However, the current study adopted the descriptive and field analytical methodology. Hence, the researcher used both methodologies by reviewing the literature related to the study variables that includes just in time system and the operational excellence and analyzing the data collected from respondents' answers on the questionnaire items.

\subsection{Study Population and Sample}

The study population consisted of (14) industrial companies operating at $\mathrm{Al}$-Hussein bin Abdullah II qualified industrial zone (QIZ) in Al-Karak Governorate. The study sample included all the study population. The sampling unit and analysis (respondents) included (168) manager and head of divisions at the production and logistic departments and selected purposely according to their work especially in the just in time system aspect within the target companies. Table (1) shows the study sample characteristics (respondents') includes the gender, years of experience in the company and their ages. 
Table1. The study sample characteristics

\begin{tabular}{llll}
\hline Variable & Category & Frequency & Percentage \\
\hline Gender & Male & 140 & 83.00 \\
& Female & 28 & 17.00 \\
\hline Years of experience & Less than (5) years & - & - \\
& From (5) to less than (10) years & 45 & 27.00 \\
& From (10) to less than (15) years & 48 & 29.00 \\
& From (15) to less than (20) years & 55 & 33.00 \\
& (20) years and above & 20 & 11.00 \\
\hline Age & From (18) to (25) years & 37 & 00.22 \\
& From (26) to (32) years & 22 & 13.00 \\
& From (33) to (40) years & 43 & 26.00 \\
& (41) years and above & 66 & 39.00 \\
\hline Total & & 168 & $100 \%$ \\
\hline
\end{tabular}

\subsection{Study Instrument}

The study instrument involved a questionnaire developed based on the theoretical literature associated with the just in time system and operational excellence. The questionnaire consists of three sections: The first section covers the demographic data of the study sample, such as the gender, years of experience and the age of respondents. The second section of the questionnaire includes the items related to the just in time system, which adopted from (Khaireddin, Abu Assab \& Nawafleh, 2015; Bellm, 2015) that measured by (16) items. The third section of the questionnaire includes the items related to the operational excellence that measured by (9) items adopted from (Shehadeh et al., 2016) with modifications by the researcher. The answers to the second and third section of questionnaire depend on a Likert Scale, extending from strongly disagree (1); disagree (2); moderately agree (3); I agree (4); and strongly agree (5).

\subsection{Instrument Validity}

The questionnaire was reviewed by groups of experts and professional in the field of business administration and based on their opinions; the paragraphs and statements of questionnaire is very clear and the questionnaire is suitable to the current study.

\subsection{Instrument's Reliability}

The instruments reliability is measured by Cronbach alpha coefficients which used to make sure there is internal consistency among questionnaire items. The alpha values was $(0.83)$ for the just in time system and $(0.85)$ for operational excellence items and (0.79) for the instrument as a whole. However, the values are excellent because it is higher than the acceptable value $(60 \%)$ and therefore, it's acceptable for the aims of current study.

\section{Results and Discussion}

\subsection{Data Presentation}

The means and standard deviations for the respondent's answers on the questionnaire items related to the just in time system and operational excellence introduced in the table (2) and table (3). Where table (2) shows the means and standard deviations for the just in time system and the respondent's answers on the questionnaire items, whereas table (3) shows the means and standard deviations for the operational excellence and the respondent's answers on the questionnaire items. 
Table 2. Show the means and standard deviations for the just in time system and the (respondent's) answers on the questionnaire items

\begin{tabular}{|c|c|c|}
\hline Equipment layout & Means & $\begin{array}{l}\text { Standard } \\
\text { deviation }\end{array}$ \\
\hline 1. We have laid out the floor so that processes and machines are in close proximity to each other. & 3.65 & 0.824 \\
\hline 2. We have eliminated many long conveyors to move materials. & 3.79 & 0.631 \\
\hline 3. Our machines are grouped according to the product family to which they are dedicated. & 4.00 & 0.863 \\
\hline 4. The layout of our floor facilitates low inventories and fast throughput. & 3.86 & 0.898 \\
\hline 5. We have located our machines to support JIT production flow. & 4.02 & 0.897 \\
\hline Average & 3.864 & \\
\hline Suppliers quality & Means & $\begin{array}{l}\text { Standard } \\
\text { deviation }\end{array}$ \\
\hline 6. Quality is our main criterion in selecting suppliers. & 3.85 & 0.891 \\
\hline 7. We rely on a small number of high-quality suppliers. & 3.59 & 0.574 \\
\hline 8. Our suppliers are actively involved in our new product development process. & 4.10 & 0.764 \\
\hline 9. We strive to establish long-term relationships with suppliers. & 3.92 & 0.659 \\
\hline 10. Our suppliers are certified for quality. & 4.40 & 0.840 \\
\hline Average & 3.972 & \\
\hline Setup time reduction & Means & $\begin{array}{l}\text { Standard } \\
\text { deviation }\end{array}$ \\
\hline 11. We are aggressively working to lower setup times in our plant. & 3.83 & 0.879 \\
\hline 12. Our crews practice setups, in order to reduce the time required. & 3.80 & 0.961 \\
\hline 13. We have low setup times of equipment in our plant. & 4.12 & 0.650 \\
\hline Average & 3.916 & \\
\hline Pull production & Means & $\begin{array}{l}\text { Standard } \\
\text { deviation }\end{array}$ \\
\hline $\begin{array}{l}\text { 14. Our production schedule is designed to allow for catching up, due to production stoppings because of } \\
\text { problems (e.g. quality problems). }\end{array}$ & 4.00 & 0.621 \\
\hline 15. We mainly produce according to forecasts. & 3.00 & 0.422 \\
\hline 16. We deliver to our customers in a demand-oriented JIT way instead of a stock-oriented approach. & 3.75 & 0.534 \\
\hline Average & 3.583 & \\
\hline
\end{tabular}

Table 3. Show the means and standard deviations for the operational excellence and the respondent's answers on the questionnaire items

\begin{tabular}{|c|c|c|}
\hline Operational excellence & Means & Standard Deviations \\
\hline $\begin{array}{l}\text { 17. The company is always improving the operational excellence by } \\
\text { Reducing the defect rate in manufacturing processes }\end{array}$ & 3.37 & 0.929 \\
\hline $\begin{array}{l}\text { 18. The company is always improving the operational excellence by } \\
\text { Reducing complexity and lead time needed }\end{array}$ & 4.18 & 0.952 \\
\hline $\begin{array}{l}\text { 19.The company is continuously strive to reduce the operational } \\
\text { Cost }\end{array}$ & 3.00 & 0.995 \\
\hline $\begin{array}{l}\text { 20.Our company overhead cost is less than our competitors in the } \\
\text { same sector }\end{array}$ & 3.57 & 0.837 \\
\hline 21. To deal with effort variability, the company use some strategies & 2.98 & 1.312 \\
\hline $\begin{array}{l}\text { 22.we rely on our operational strategy to deal with arrival variability, the company use } \\
\text { the operation Strategies }\end{array}$ & 3.95 & 0.795 \\
\hline 23. To deal with arrival variability, the company uses some strategies & 2.78 & 1.174 \\
\hline 24. To deal with request variability, the company uses some strategies & 2.99 & 1.329 \\
\hline 25. To deal with capability variability, the company use some strategies & 3.90 & 0.820 \\
\hline Average & 3.413 & \\
\hline
\end{tabular}

\subsection{Hypotheses Testing}

The current study used the following test to guarantee suitability of data for the regression analysis assumptions 
such as Variance Inflation Factory (VIF) and Tolerance Test in order to confirm there is no high correlation between the independent variables (Multicollinearity) (equipment layout, suppliers quality, Set up time reduction and pull production) and Skewness Test to ensure the normal distribution of the data. The results of these tests presented in Table 4.

Table 4. Shows the VIF, Tolerance, and Skewnes tests results

\begin{tabular}{llll}
\hline Independent Variables & VIF & Tolerance & Skewness \\
\hline Equipment layout & 2.85 & 0.440 & 0.558 \\
Suppliers quality & 2.79 & 0.431 & 0.533 \\
Set up time reduction & 2.66 & 0.436 & 0.498 \\
Pull production & 2.38 & 0.408 & 0.481 \\
\hline
\end{tabular}

The results in the above Table (4) refer to the values of Variance Inflation Factory less than (10) for all variables and also the Tolerance values are higher than $(0.05)$ that is indicate there is no high correlation (Multicollinearity) between the independent variables (equipment layout, suppliers quality, Set up time reduction and pull production). And the results in the Table 4 explained that the Skewness values are less than (1) which indicates that there is a normal distribution of the data. According to these results the researcher was conducted the multiple linear regression analysis in order to test the study hypothesis. Table (5) shows the model summary, while the Table (6) shows ANOVA analysis and whereas the Table (7) shows beta and t values for the study hypothesis.

Table 5. The Model summary

\begin{tabular}{lllll}
\hline Model & $\mathrm{R}$ & R Square & Adjusted R Square & Std. Error of The Estimate \\
\hline 1 & 0.824 & 0.672 & 0.729 & 0.337 \\
\hline
\end{tabular}

*Predictors: (Constant), Equipment layout, Suppliers quality, set up time reduction, Pull production.

As explained in the above table (5) the results of the value of R square is (0.672) and this value indicate that the model clarifies or explains $(67 \%)$ from the variance in the dependent variable (operational excellence) by just in time system.

Table 6. ANOVA analysis

\begin{tabular}{llllll}
\hline Model & Sum of Squares & DF & Mean Square & F & Sig. \\
\hline 1 Regression & 335.207 & 3 & 52.910 & 0.000 \\
Residual & 21.309 & 165 & 0.061 & \\
Total & 356.516 & 168 & & \\
\hline
\end{tabular}

*Predictors: (Constant), Equipment layout, Suppliers quality, set up time reduction, Pull production.

**Dependent Variable: operational excellence.

As explained in the above Table (6) the results show that the value of (F) is (1063.170) with significant $(0.000)$ which is lower than the specified value (0.05) therefore, the model is fit and acceptable.

Table 7. Beta and T values for the study hypotheses

\begin{tabular}{lcccc}
\hline Model & $\begin{array}{c}\text { Unstandardized } \\
\text { B }\end{array}$ & $\begin{array}{c}\text { Coefficients } \\
\text { Std. Error }\end{array}$ & $\begin{array}{l}\text { Standardized } \\
\text { Coefficients } \\
\text { Beta }\end{array}$ \\
\hline ( Constant) & 0.072 & 0.063 & & Sig. \\
Equipment layout & 0.640 & 0.028 & 0.660 & 38.66 \\
Suppliers quality & 0.621 & 0.031 & 0.641 & 0.000 \\
Set up time reduction & 0.596 & 0.022 & 0.616 & 35.920 \\
Pull production & 0.588 & 0.019 & 0.608 & 30.420 \\
\hline
\end{tabular}

*Significant at the level of statistical significance $(\alpha \leq 0.05)$

**Dependent Variable: operational excellence. 
As shown in the above Table (7) the results of multiple regression analysis indicate that just in time system impact on the operational excellence. And the values of beta and t-tests explained that the following practices: equipment layout, supplier's quality, set up time reduction and pull production has a positive impact on operational excellence at $(\alpha \leq 0.05)$.

\section{Conclusion}

Empirical results found that the just in time system included (Equipment layout, Suppliers quality, Set up time reduction and Pull production) have a positive impact on the operational excellence in Jordanian industrial companies. According to these results the study recommending that the Jordanian industrial companies must emphasis essentially and mainly on their just in time system consisted of (equipment layout, supplier's quality, Setup time reduction; Pull production) in order to enhance and attain the operational excellence and gain competitive advantage.

\section{Limitations and Future Researches}

One of the most limitations is that the current study and its finding applied on the Jordanian industrial companies especially at Al-Karak governorate. Therefore, the results of present study can't generalize on the other sectors. Therefore, there is a need to conduct more studies and research on the other sectors such as food Industry and pharmaceutical industries in order to generalize the results. In addition to, conducting comparative studies with other industrial areas located in Jordan.

\section{References}

Abdallah, A. B., \& Matsui, Y. (2007). The relationship between JIT production and Manufacturing strategy and their impact on JIT performance, POMS 18th annual conference Dallas, Texas, U.S.A. May 4 to May 7.

Abdallah, A., \& Phan, A. (2007). The Relationship between Just-In-Time Production and Human Resource Management, and Their Impact on Competitive Performance. Yokohama Business Review, 28(2), 27-57.

Adnan, A. N. B., Jaffar, A. B., Yusoff, N. B., \& Halim, N. H. B. A. (2013). Implementation of Just in Time Production through Kanban System. Industrial Engineering Letters, 3(6).

ALshbiel, S. O., \& Al-Awaqleh, Q. A. (2012). JIT production system and its effect on achieving competitive advantage for public shareholding industrial companies in Jordan. Interdisciplinary Journal of Contemporary Research in Business, 4(6).

Bellm, D. (2015). Operational Excellence in the Pharmaceutical Industry-An Architecture for Emerging Markets. unpublished dissertation of the University of St. Gallen, School of Management, Economics, Law, Social Sciences.

Drury. C. (2002). Management Accounting for Business Decisions. United States: Thomson.

Eker, M., \& Pala, F. (2008). The Effect of Competition, Just In Time Production and Total Quality Management on the Use of Multiple Performance Measures: An Empirical Study. Journal of Economic and Social Research, 10(1), 35-72.

Eriksson, P., pettersson, A., \& Shokatloo, S. (2012). Assessment of leadership aspects that contribute to Operational Excellence: A case study of two large companies in Sweden. Blekinge Institute of Technology.

Evans, J. R. (1997). Applied Production and Operations Management (5th ed.). West Publishing Co., U.S.A.

Fok-yew, O. A. H., \& Baharin, S. (2013). Operational Excellence and Change Management in Malaysia Context. Journal of Organizational Management Studies.

Gupta, A. K. (2012). Just in Time Revisited: Literature Review and Agenda for Future Research. International Journal of Research in Mechanical Engineering \& Technology, 2(1), 59-63.

Gyampah, K., \& Gargeya, V. (2001). Just-in-Time manufacturing in Ghana. Industrial Management \& Data Systems, 101(3), 106-113.

Horngren, C. T., Foster, G., \& Dater, S. N. (2000). Cost Accounting. New Jersey: Hall International.

Hou, B. C., Hing, K., \& Wang, X. J. (2011). A Case Study of Just-In-Time System in the Chinese Automotive Industry. Proceedings of the World Congress on Engineering, London, U.K, 1.

Ifeanyichukwu, O. C. (2010). Organizational performance improvement in an oil Producing facility in Nigeria through operational excellence, unpublished dissertation submitted in partial fulfillment of the requirements for the degree Master of Engineering at the Potchefstroom Campus of the North-West University, South Africa. 
Ion, N., Radu, C., \& Cioana, G. (2013). Operational excellence - A key to world class business performance.

Islam, Q. T. (2017). Quality Operation Management Strategy as an Indication of Organizational Success. International Journal of Management Sciences and Business Research, 6(2).

Jaegera, A., Matyasb, K., \& Sihn, W. (2014). Development of an assessment framework for Operations Excellence (OsE), based on the paradigm change in Operational Excellence (OE), Variety Management in Manufacturing. Proceedings of the 47th CIRP Conference on Manufacturing Systems, 17, 487-492.

Kaneko, J., \& Nojiri, W. (2008). The logistics of Just-in-Time between parts suppliers and car assemblers.

Kannan V., \& Tan, K. (2005). Just in time, total quality management, and supply chain management: understanding their linkages and impact on business performance. The International Journal of Management Science, 33, 153-162.

khaireddin, M., Mohammad, I. E., \& Sahem, A., Abu, A. N. (2015). Just-in-Time Manufacturing practices and Strategic Performance: An Empirical Study Applied on Jordanian Pharmaceutical Industries. International Journal of Statistics and Systems, 10(2).

Kinyua, B. K. (2015). An assessment of just in time procurement system on organization performance: A case study of corn products Kenya limited. European Journal of Business and Social Sciences, 4(5).

Kootanaee, A. J., Babu, K. N., \& Talari, H. F. (2013). Just-in-Time Manufacturing System: From Introduction to Implement. International Journal of Economics, Business and Finance, 1(2), 7-25.

Lewis, M. (2000). Lean production and sustainable competitive advantage. International Journal of Operations \& Production Management, 20, 214.

Lu, D., Betts, A., \& Croom, S. (2011). Re-investigating business excellence: Values, measures and a framework. Total Quality Management, 22(12), 1263-1276.

Madanhire, I., Kagande, L., \& Chidziva, C. (2013). Application of Just In Time (JIT) Manufacturing Concept in Aluminium Foundry Industry in Zimbabwe. International Journal of Science and Research (IJSR), 2(2).

Mastui, Y. (2007). An empirical analysis of just-in-time production in Japanese Manufacturing companies. International Journal of Production Economics, 108, 153-164.

Mazanai, M. (2012). Impact of just-in-time (JIT) inventory system on efficiency, quality and flexibility among manufacturing sector, small and medium enterprise (SMEs) in South Africa. African Journal of Business Management, 6(17).

Miltenburg, J. (2001). U-shaped production lines: A Review of Theory and Practice. International Journal of Production Economics, 70, 201-214.

Poojary, A., \& Kumar, S. (2015). Just in Time (JIT): A tool to decrease cost and to improve profitability. International Journal of Management \& Business Studies, 5(1).

Porter, M. E. (1996). What is strategy? Operational effectiveness is not strategy. Harvard Business Review, 74(6), 61-79.

Rahmani, K., \& Nayyebi, M. A. (2014). Effect of JIT implementation in Iran automotive industry, case study: Iran.

Ramezani, A. R., \& Razmeh, A. P. (2014). Basic elements, tools and control techniques of Just-in-time System. Academic Journal of Research in Business \& Accounting, 2(9), 11-22.

Russell, R. H., \& Koch, J. I. (2009). Operational Excellence, the New Lever for Profitability and Competitive Advantage. A Palladium Group White paper.

Schroeder, R. G., Goldstein, M., \& Rungtusanatham, M. J. (2011). Operations management, contemporary concepts and cases (5th ed.).

Serfonten, J. J. (2010). The impact of strategic leadership on the operational strategy and performance of business organization in South Africa. unpublished dissertation presented for the degree of philosophies.

Shehadeh, R. M., Maqableh, M., Al-Zoubi, M. O., Akhorshaideh, A. H. O., \& Al-Shami, M. K. (2016). Review the Operational Excellence Factors of Service Firms: A Literature Review. European Journal of Business and Management, $8(3)$.

Singh, C., Singh, R., Mand, J. S., \& Singh, S. (2013). The application of lean and JIT principles in supply chain management. International Journal of Management Research and Business Strategy, 2(1). 
Singh, G., \& Ahuja, I. S. (2012). Just-in-time manufacturing: literature review and directions. International Journal of Business Continuity and Risk Management, 3(1).

Singh, S., \& Garg, D. (2011). JIT System: Concepts, Benefits and Motivation in Indian Industries. International Journal of Management \& Business Studies, 1(1).

Stevenson, M., Hendry, L. C., \& Kingsman, B. G. (2005). A review of production planning and control: the applicability of Key Concepts to the Make-to-order Industry. International Journal of Production Research, 43(5), 869-898.

Voss, C. A., \& Robinson, S. J. (1987). Application of Just-in-time manufacturing techniques in the UK. International Journal of Operations and Production management, 7(4), 46-52.

Wong, C. Y., \& Johansen, J. (2006). Making JIT retail a success: The coordination journey. International Journal of Physical Distribution \& Logistics Management, 36(2), 113-126.

Yew, O. F., \& Ahmad, H. (2014). The Effect of Change Management on Operational Excellence moderated by Commitment to Change: Evidence from Malaysia. International Journal of Innovation and Applied Studies, $9(2), 615-631$.

Yew, O. F., Ahmad, H., \& Baharin, S. (2013). Operational Excellence and Change Management in Malaysia Context. Journal of Organizational Management Studies, 14.

\section{Copyrights}

Copyright for this article is retained by the author(s), with first publication rights granted to the journal.

This is an open-access article distributed under the terms and conditions of the Creative Commons Attribution license (http://creativecommons.org/licenses/by/4.0/). 